DOI 10.22394/2073-2929-2021-02-120-131

\title{
Economic and Political Aspects of the Serbia - EAEU Free Trade Area
}

\section{Andrey V. Toropygin}

Russian Presidential Academy of National Economy and Public Administration (North-West Institute of Management of RANEPA), Saint Petersburg, Russian Federation; toropyginav@mail.ru

\section{ABSTRACT}

The article is devoted to the analysis of the Serbia - EAEU relations development through the prism of the Agreement on the Free Trade Area (FTA) - between the integration association and the separate economy / country. The purpose of this study is to identify the prospects of the FTA taking into account Serbia's desire to integrate into the European Union. The author come to the conclusion that intensive interaction, primarily between Serbia and Russia through the FTA between Serbia and the EAEU, is explained, on the one hand, by Serbia's multi-vector foreign policy, and, on the other hand, by Russia's attentive attitude to the course of the conflict over Kosovo. Russia has economic interests in this region, as well as the region is people-related value for Russia within which it has used and will intensively utilize of soft power mechanisms.

Keywords: Integration processes, Free Trade Area, Russian-Serbian relations, the EU, the EAEU, soft power

For citing: Toropygin A. V. Economic and Political Aspects of the Serbia-EAEU Free Trade Area // Eurasian integration: economics, law, politics. 2021. No. 2. P. 120-131.

\section{Экономические и политические аспекты зоны свободной торговли Сербия - ЕАЭС}

\section{Торопыгин А. В.}

Российская академия народного хозяйства и государственной службы при Президенте Российской Федерации (Северо-Западный институт управления РАНХиГС), Санкт-Петербург, Российская Федерация; toropyginav@mail.ru

\section{PEФЕРAT}

Статья посвящена анализу развития отношений Сербия - ЕАЭС через призму Соглашения о зоне свободной торговли (ЗСТ) - между интеграционным объединением и отдельной экономикой / страной. Целью данного исследования является определение перспектив ЗСТ с учетом стремления Сербии интегрироваться в Европейский союз. Автор приходит к выводу, что интенсивное взаимодействие, прежде всего между Сербией и Россией в рамках этой ЗСТ, объясняется, с одной стороны, многовекторностью внешней политики Сербии, а с другой - внимательным отношением России к ходу конфликта вокруг Косово. У России есть экономические интересы в этом регионе, но для нее не менее важны и дружеские отношения с сербским народом, являющиеся не меньшей ценностью, что диктует активное использование механизмов мягкой силы.

Ключевые слова: интеграционные процессы, зона свободной торговли, российско-сербские отношения, ЕС, ЕАЭС, мягкая сила

Для цитирования: Торопыгин А. В. Экономические и политические аспекты зоны свободной торговли Сербия - ЕАЭС // Евразийская интеграция: экономика, право, политика. 2021. № 2. С. 120-131.

\section{Introduction}

The modern political and economic science pays close attention to the situation in the Western Balkans. The focus is on their efforts towards the European integration and the persistent issues that arise from, in 
particular, volatile inter-ethnic relations and political turmoil. In the Western Balkans, the regional economic integration is considered to be the main vector of the economic growth and development of the whole region, in which Serbia has a key role as the central country of this region. The challenging political environment appears to be a significant aspect affecting stability and further extension of the integration. As a result, the dialogue between Serbia and Kosovo has not reached normalisation of relations yet and there is still a risk of potential conflict. Considering Serbia's foreign policy, it is important to note that the country has always aimed at keeping a balance between the Russian Federation and the West. To enhance the cooperation, the leaders of Serbia and the EAEU have signed a Free Trade Agreement between the Eurasian Economic Union and the Republic of Serbia on October 25, 2019. Over the past 20 years, Serbia has signed similar agreements with the key countries of the EU. It is important to emphasise that the format of integration within the EAEU can serve as a sort of alternative to the European integration with respect to trade and economic cooperation and, simultaneously, it could assign the role of a "bridge" in the economic and political relations between Russia and the West through Serbia. This mechanism of cooperation effectively enhances the economic element, which is needed to join the EU successfully, as robust economy facilitates the integration processes. The EAEU was established in compliance with rules and regulations of the World Trade Organisation (WTO), its format is in some aspects similar to that of the European Union (EU), and its constitutional documents were based on the corresponding documents of the EU, hence posing no political and legal collision. As a sovereign state, Serbia has the right to sign any agreement in accordance with its national interest and foreign policy goals.

The mechanism of cooperation between the EAEU and Serbia enhances competitiveness and reinforces the implementation of national interests, and, at the same time, it enables Serbia to become one of the key elements between the EU and the EAEU. This way of cooperation provides the opportunity to choose pragmatic alternatives and mutually beneficial projects within both European and Eurasian zones. Thus, given the geographical position and the significance of the Balkans, the region is an open gateway to the EU's market, and, at the same time, it can be instrumental in terms of objectives of China and Russia [12, p. 140].

\section{Russia - Serbia: Reality and perspectives on further cooperation}

The first Agreement on Free Trade between the Federal Republic of Yugoslavia and the Russian Federation was signed by the Federal Government of the Federal Republic of Yugoslavia and the Government of the Russian Federation on August 28, 2000 in Belgrade. The Goals of the Agreement were: to stimulate trade and economic relations; to improve labour and living conditions; to increase employment; to achieve industrial and financial stability; to create conditions for fair competition between business entities; to harmonise customs procedures and rules of origin.

The Parties agreed to liberalise mutual trade in compliance with the rules of the WTO in order to establish a free trade system. The Parties were certain that this agreement would enhance economic development of both states and improve the standards of living. Yet in 2018, according to the Statistical Office of the Republic of Serbia, the EU accounted for 67 percent of the country's export and 60 percent of its import. Russia accounted for only 5.3 percent and 7.7 percent respectively ${ }^{1}$. Since October 2000, 97 percent of commodities arrive to the custom territories of Russia and Serbia on the duty-free basis. Up to the following year, such technical issues as exemption from the free trade system, origins of commodities, etc. had been resolved. At the same time, the lists of goods to be included in the Agreement were revised regularly. On July 22, 2011 the Russian and Serbian governments signed the Protocol on exemption from free trade and Rules of origin. On the Serbian part, a unified set of rules for certain EAEU members such as Belarus, Kazakhstan, and Russia were approved [6].

Among the experts, there were various opinions with respect to evaluation of the trade success between these two countries. Yet the common idea implied that the trade extension itself was the right course.

\footnotetext{
1 Sheiko Y. Serbii pridetsya vybirat' mezhdu ES i zonoy svobodnoy torgovli s EAES [Serbia Will Have to Choose between the EU and a Free Trade Zone with the EAEU] // Deutsche Welle, October 25, 2019 [Электронный ресурc]. URL: https://www.dw.com/ru/сербии-придется-выбирать-между-ес-изоной-свободной-торговли-с-еаэс/а-50976789 (дата обращения: 20.08.2020).
} 
The Free Trade Agreement between Serbia and the Republic of Belarus was signed in Minsk in 2009. In 2011, it was complemented with the Protocol of exemption of a number of goods from the free trade system.

The Free Trade Agreement between Serbia and Kazakhstan was signed in 2010 and came into force in 2011. It introduced duty-free import to both countries with the exception of goods.

In terms of international business, Serbia's main trade partners are the EU, countries of the Central European Free Trade Agreement (CEFTA), Russia, and China ${ }^{1}$.

In light of trade liberalisation it is important to note that the trade turnover between Serbia and the EU amounted to 26 billion euro ${ }^{2,3}$. Serbia has significantly benefited from the trade and economic integration with the EU. Historically, the EU has been the main trade partner for Serbia; as of 2019, it accounts for around 65 percent of the total Serbian export and around 64 percent of the total Serbian import. The ratio has revolved around similar numbers for many years. According to the data, the value of the Serbian export in the EU has more than tripled since 2009, when it amounted to 3.4 billion euro, to 2019 and almost 11.3 billion euro ${ }^{4}$. The Serbian export to EU has shown a faster growth than the Serbian import from the EU. The data shows that the direct foreign investment from the EU amounted to almost 70 percent of the total volume of foreign direct investment received over the past 10 years from 2010 to $2019^{5}$. As it is specified, over the past ten years the absolute value of the foreign direct investment from the EU countries has overstepped 15 billion euro. Considering the foreign trade figures, one can conclude that members of the EU are Serbia's leading trade partners; countries of the CEFTA are second important after the EU. Serbia has a trade surplus with them, and they account for more than 17 percent of the total trade turnover of the country and around 30 percent of the Serbian export [6].

Thus, to establish a Free Trade Area (FTA) with Serbia, the top priorities are to convert the existing agreements to a common denominator, to finalise exemption lists, and to bring Armenia and Kyrgyzstan to the table. History of FTA agreements shows that if business sector engages more actively, the free trade agreement will be implemented more efficiently. To maximise potential benefits of the FTA, manufacturers and business communities of both the EAEU and Serbia have to take an important part in the process as they can assess potential development and issues related to selling goods and services at third countries' markets.

The second Free Trade Agreement between the Eurasian Economic Union and its Member States on one part, and the Republic of Serbia on the other part, is more sizeable: it comprised 33 articles and 68 pages. The goals of this agreement were, along with trade extension and industrial and financial stability, to create efficient procedures with respect to implementation of provisions of the Agreement. This is obviously connected to a rule of the next article "Correlation with other international agreements" (Article 3). It stipulates that if there occurs a contradiction with the provisions of the Marrakesh Agreement Establishing the WTO signed on April 15, 1994, the provisions of the WTO Agreement shall prevail. In such case, the Parties are to cooperate to achieve a mutually approved solution.

The Agreement establishes a Mutual committee with a task to review all the matters occurring in the process of implementing and fulfilling the Agreement in the interest of trade development. Contact points are established to resolve matters of implementation of the Agreement.

One might say that the Agreement mainly relies on the WTO provisions. For the countries who are not members of this organisation it is crucial.

\footnotetext{
1 The Serbian statistics for 2016 showed that in the total trade volume with Serbia, Germany accounted for a share of 12.9 percent, Italy for 12.25 percent, Russia for 6.8 percent, Bosnia and Herzegovina for 5 percent, China for 4.7 percent, Romania for 4.1 percent, Hungary for 4 percent; together, they account for half of the Serbia's trade turnover. Among the main exporters to the Serbian market are: Germany with a percentage share of 12.9 percent, Italy (10.3 percent), China (8.3 percent), Russia (7.9 percent), Hungary (4.6 percent), Poland (4.3 percent), Turkey ( 3.5 percent) and France ( 3 percent); together, they account for 54.8 percent of the total import in Serbia. The main importers of Serbian commodities are Italy (with a percentage share of 14.6 percent), Germany (13 percent), Bosnia and Herzegovina (8.3 percent), Romania (5.7 percent), Russia (5.3 percent), Montenegro (4.9 percent) and Macedonia (3.5 percent); together, they account for 53.3 percent of the total Serbian export.

2 European Commission, "European Union, Trade with Serbia" [Электронный ресурc]. URL: https://webgate.ec.europa.eu/isdb_results/factsheets/ country/details_serbia_en.pdf (дата обращения: 15.11.2020).

3 Delegation of the European Union to the Republic of Serbia, "Serbia - EU Trade Liberalisation" [Электронный ресурс]. URL: http://europa.rs/serbiaand-the-eu/trade/?lang=en (дата обращения: 15.11.2020).

4 Delegation of the European Union to the Republic of Serbia, "Serbia and the EU" [Электронный ресурc]. URL: https://eeas.europa.eu/delegations/ serbia/27547/serbia-and-eu_en (дата обращения: 15.10.2020).

5 Delegation of the European Union to the Republic of Serbia, "Serbia - EU Trade Liberalisation".
} 
With respect to legislative unification, Serbia, as well as other Western Balkan (WB) countries, undergoes the unification in accordance with the EU regulations. There are tables describing that process in the work of E. Tosheva and B. Dimeski [14]. Obviously, these aspects depend on a model of integration.

It is important to emphasise that modern FTA agreements are complex, and they cover both trade and other areas such as access to service and investment markets, labour force movement, competition policies, access to state purchasing, security of intellectual property, and others. Consequently, a Free Trade Area between the EAEU and Serbia should not be limited by trade matters. There is still great potential in other areas (agro-industrial complex, industrial cooperation, construction, development and modernisation of infrastructure, transport, etc.), which, however, has not yet been realised in a befitting way.

In terms of FTA cooperation with Serbia, the EAEU can substantially benefit from broader market channels and stronger cooperation with the whole Balkans region; furthermore, it can utilise preferential reciprocity in a number of ways: to diversify investment partnerships, to extend industrial, agricultural and technological cooperation, to intensify cooperation in the field of secondary sector and high-tech industries, and to improve the dialogue with Europe.

As for Serbia, the main benefits may involve fulfillment of its trade and investment potential within the Eurasian area.

At the beginning of November 2019, Serbia signed the Free Trade Agreement with the members of the EAEU. The Agreement solved a number of technical issues:

- it harmonises tariffs and other conditions that regulate trade between Serbia and Belarus, Kazakhstan, and Russia;

- $\quad$ it enables the parties to create a similar system for goods originating from Armenia and Kyrgyzstan; before, they did not have the preferential access to the Serbian market;

- it enables the parties to update the regulatory part of the agreement when it concerns protective anti-dumping measures, settlement of disputes, and rules of origin;

- $\quad$ it opens a brand-new market for goods from Armenia and Kyrgyzstan with duty-free access for the major part of export volume. In addition, it creates new export opportunities for manufacturers from Belarus, Kazakhstan, and Russia;

- it will boost the extension of cooperation between the EAEU and Serbia. Economies of Serbia and the EAEU countries will benefit both short-term, as it entails an instant cut of customs payments on export and import, and mid-term, as the export opportunities within the frames of free trade will be extended to a larger range of goods;

- it will enable Armenia, Kyrgyzstan, and Kazakhstan to increase the volume of traditional export: food industry and agricultural raw materials;

- Tigran Sarkisyan, Chairman of the Board of the Eurasian Economic Commission (EEC), has made an official statement in which he announced that the EAEU is planning to create a unified preferential trade regime for all countries of the Union;

- Belarus can exercise the opportunity to increase its export of textile and machinery. Russian manufacturers will be able to extend their supply of a wide range of goods - from isolation valves and mixer taps to agricultural produce - to Serbia;

- Serbia will obtain a similar set of trade and export opportunities, as in its turn, it will be able to sell its agricultural produce;

- The EAEU and Serbia are planning to extend the list of items subject to duty-free export and import in 2020-2022. The volume of manufactured goods supplied by Serbia to the EAEU will increase at least by one third, of the agro-industrial goods at least by a quarter. To conclude, the benefits are more than long-term and multilateral;

- The arrangements with Serbian partners establish mutual obligations in relation to international standards implemented in licensing, temporary embargoes and quantitative limits, technical regulation, sanitary and phytosanitary measures; 
- It is also applied to charges related of board control procedures, to anti-dumping, compensatory and specific protective measures, to intellectual property rights protection.

According to the experts, the current situation is almost identical to the circumstances of 2016. At that time, the Russian International Affairs Council considered three scenarios:

1. Europe-oriented development vector. A temporary agreement which Serbia would withdraw from when joining the EU. The Eurasian integration would smoothly move to the background. This position is comprehensible, as Serbia would have to follow the common policies of the EU (scenario No. 1).

1. A potential ally of the EU. Serbia would become dependent on the course of the EU's development, or, what is more precisely, on the American perspective on development of Europe (scenario No. 2).

2. "A Bridge between Europe and Eurasia scenario." This scenario (less plausible in today's circumstances) implies that Serbia retains the Free Trade Area Agreement with the EAEU while being a member of the EU. This scenario is obviously highly advantageous. In this case, however, other countries' positions would have more weight than Serbia itself (scenario No. 3).

In fact, the Agreement serves two, as one can say technical functions. Firstly, it completely harmonises trade conditions of Belarus, Kazakhstan, and Russia with Serbia. Secondly, it creates a similar system for Armenia and Kyrgyzstan who did not have preferential access to the Serbian market before.

This was confirmed by the Chairman of the Board of the EEC when he stated that during the negotiations, the parties had managed to update the regulatory part of the Agreement which then included the most recent legislative developments, particularly in terms of protective measures, settlement of disputes, and rules of origin.

The arrangements in effect entail economic benefits for the EAEU countries and Serbia in short-term, which arise from the instant cut of the customs payments relating to the current export, as well as in mid-term, since the extension of the free trade system will facilitate export opportunities.

Apart from tariff obligations, the Agreement provides a set of legislative developments with the aim to ensure stability, predictability, and transparency of trade operations.

Serbia is not a WTO member, and it was important to establish a whole set of obligations in relation to international standards implemented in licensing, embargoes and quantitative limits, technical regulation, sanitary and phytosanitary measures, charges related to "board control" procedures, to anti-dumping, compensatory and specific protective measures, to intellectual property rights protection.

Is it possible for this to replace the multi-directional relation development with Russia and other "key actors" outside of the Euro-Atlantic camp? It would imply reinforcement of trade and economic relations with Moscow and its allies within the Eurasian area.

The EAEU serves as a framework that can provide sort of alternative to the European integration with respect to trade and economic cooperation and, simultaneously, assign the role of a "bridge" in the economic and political relations between Russia and the West to Serbia. Serbia has already become the 73rd member of the Asian Infrastructure Investment Bank with its global headquarters in Beijing (the bank started operation in 2016).

If this document becomes effective, it will mean a fundamentally different level of Belgrade's presence within the Eurasian area; Serbia will enter the market with a number of potential consumers of more than 182 million people and total GDP of more than 1.9 trillion US dollar. Thus, Serbia may become one of the links between the EU and the EAEU.

The Free Trade Area Agreement is a result of technical negotiations. Over the past 20 years, Serbia has signed similar agreements with the key countries of the EU. It is a bureaucratic exercise of a sort; it does not affect the quality of economic cooperation with the Five.

As for having it both ways, it is mostly a speculation, as well as the statement about Serbia choosing something again, signing something, choosing a path, etc. It must be underlined that the EAEU was initially created in legal compliance with rules and regulations of the WTO, in the format similar to that of the EU. In addition, the EAEU's constitutional documents were based on the corresponding documents of the EU. In this 
regard, the EAEU creates a regulatory, legal and technical foundation for the potential cooperation between the EAEU and the EU, and there is no political and legal collision in this ${ }^{1}$.

Generally, a country has to meet certain criteria to be eligible to join the EU. As for the economic issues, many experts have noted that as the reforms gain momentum, the obligations to fulfill become more and more complex as there is a requirement to decrease the volume of agricultural production, to restructure a number of industries, to denationalise a number of infrastructures. Inevitably, this leads to a deterioration of living standards [16, p. 347]. Evidently, to be able to join the EU successfully, a country needs quite a robust economy. To avoid a negative scenario, all the available options are to be utilised. From that perspective, the possibility to take a loan to develop domestic production and selling markets appears to be a fully justified measure.

\section{EU - Serbia Integration Development}

A number of experts from the Western Balkan states highlights that in the modern era, the Western integration is the only political and economic option for the Balkans [13].

Along with the other five WB countries, Serbia was appointed a potential candidate country during the meeting of the European Council in Thessaloniki in 2003. The European partnership with Serbia was launched in 2008, and within this process it was determined that Serbia can apply for the EU membership in 2009. In 2012, the country was granted the candidate status, the status was confirmed, and the European Council approved the recommendation to start formal negotiations with Serbia. The Stabilisation and Association Agreement between the European Communities and their Member States, of the one part, and the Republic of Serbia, of the other part finally came into force in September 2013. The negotiations were opened in 2014. As of May 2019, 16 out of 35 chapters had been closed within the negotiation framework. One can state that the process is being paid for during the negotiations. Serbia has received a total amount of 2.7 billion euro for the accession negotiations between 2007 and 2020. Yet there were certain obstacles. For instance, in October 2019, the European Parliament initiated interparty cooperation with the Serbian parliament in order to improve election conditions concerning the remaining matters that incited a part of the opposition to start a boycott.

In 2018, EU Commissioner for European Neighbourhood Policy and Enlargement Negotiations gave an interview to Reuters in which he mentioned that Serbia and Montenegro can become member states in 2025; on the one hand it is realistic, but on the other hand it is ambitious. It was noted that the EU's politicians have somewhat lost the interest towards the enlargement of the bloc due the rise of Euroscepticism, the Eurozone crisis of 2009-2013, and Britain's decision to leave the Union. In light of this, the EU leadership is striving to connect the accession of the Balkan countries to struggle against corruption, organised crime, and authoritarian threat in the region. The stakes are on Serbia. France is manifesting the idea of prioritising internal issues to the detriment of enlargement acceleration [4, p. 23]. Emmanuel Macron has repeatedly offered respective proposals. If the new structure of the EU retains its authority and confirms that its policies concerning the WB are still valid, the EU has to voice its "one vote" commitment to close cooperation with the WB countries aimed at their radical inclusion in the political and economic structure of the EU and at constituting a common foreign policy, a common security and defense policy [2, p. 198]. That is why Serbia might have to face a choice between two integration unions. As of today, the matter is resolved in the following manner: Serbia has the right to enter any agreements.

Yet the extended duration of the integration process suggests that the matter of the European integration is not Serbia's first priority. This is brought up by the following factors:

1. Serbia's economic dependency on the EU and pro-European orientation of the Serbian elite [9].

2. The military and political status of Serbia resulting from the "Agreement for support and procurement of cooperation in the field of logistical support between Serbia and the North Atlantic Treaty Organisation (NATO)" that was signed in 2015.

3. Economic and trade dependency on the countries of the EU.

\footnotetext{
1 Entina E. V SSHA obespokoyeny dogovorennostyami Serbii s EAES [US concerned about Serbia's agreements with the EAEU] // Balkanist, April 18, 2019 [Электронный ресурc]. URL: https://balkanist.ru/v-ssha-obespokoeny-dogovorennostyami-serbii-s-eaes/ (дата обращения: 20.10.2020).
} 
Thus, the mutual course of the Parties is to keep the current integration pace, as a minimum, and to accelerate it as a maximum.

Serbia highly values cooperation with other countries in the region and considers it to be a preliminary step towards the EU. Within the CEFTA framework, which contains trade rules and procedures conforming to the EU's and the WTO's regulations, there emerged, in fact, a free trade area of the WB countries. Its operation is an adaptation for the coming accession to the EU and the WTO membership. It has to be taken into account that upon entering the European integration processes, Serbia acquires a vast set of obligations, which in most cases are quite pressing, in the field of institutional reforms, development of the competitive market economy, and ensuring the adherence of the country's regulations and economy to the European standards (acquis communautaire). At the same time, the Russian experts emphasise that even though the EU launched programmes of economic and financial assistance, a few support instruments (PHARE, CARDS, IPA I, IPA II), and a pre-accession assistance policy (Stabilisation and Association Process - SAP), the European integration does not revolve around these programmes and it entails a number of considerably large expenses. The most notable one's stem from economy modernisation, highly competitive products from other countries of the EU, uncontrolled labour force migration, and the fact that some businesses that are not capable of competing at the given level and adhering to the given rules and standards will have to shut down, etc. To minimise the expenses arising from the accession to the EU, Serbia needs a certain level of economic development, which the country is not likely to achieve independently in the mid-term perspective. The EU membership will inevitably invoke further market liberalisation through competition reinforcement. In the long-term perspective, it can stimulate sustainable economic development of the Western Balkans; on the other hand, the institutional reforms need to be complemented with country-specific solutions for economic management and economic stimuli, as competition policy convergence (legislation and its implementation) is crucial to establish a functional free market, to fulfill the conditions of the Agreement on Stabilisation and Association Process with the EU, and to prepare the country for implementation of the corresponding EU policies as the country joins the Union [14, p. 47, 48].

The energy aspect of the EU countries is an important factor, too. The members of the EU take decisions on energy matters internally, as it is a part of their national security policies, while the great powers (Russia, the EU, and the United States of America / USA) as well as regional powers (Turkey) plug in the mechanisms and influence securitisation processes. As a result, the oil pipeline projects can simultaneously serve as "pipelines of peace" or as a source of rivalry, separation, and conflict [1, p. 67-77].

Serbia has decreasingly little space for a political maneuver between the dominant Euro-Atlantic vector among the elite and the pro-Russian sympathy of the population. The EU leadership is striving to deprive other global actors of the possibility to put pressure on Europe through Serbia, which appears to be the incentive for the Union to incorporate the republic as soon as possible. The EU sees Serbia as an enclave of the Russian influence in the Balkans, which is supported by the loyalty of their population; consequently, the EU has to develop its policy in the region in a "special" manner, with an emphasis on soft power [10].

The CEFTA, in fact, has been used as such a mechanism in the Western Balkans. The main goal is, however, to prepare the countries for the EU membership.

As we know, the EU utilises both an individual attitude and regional aspects. In this case, it is about regional peace-making and cooperation on one hand, and about the CEFTA structure on the other (1992). According to the original intention, this was to serve specifically as a step towards the EU membership [5, p. 9]. In 1995, the CEFTA was declared an open organisation with the following eligibility requirements:

- to have a trade agreement with the EU or to a status of an associated member of the European Community;

- $\quad$ to be a WTO member / a party to the General Agreement on Tariffs and Trade (GATT);

- to have a bilateral free trade agreement with each CEFTA member state [7, p. 46-47].

Such countries as Albania, Bosnia and Herzegovina, Northern Macedonia, Moldavia, Serbia, Montenegro, and the partially recognised state of Kosovo meet these requirements. 
One might say that the organisation still serves as a preparation for the EU membership. The Western Balkan countries have not created their own integration / regional system, even though it was discussed; Serbia proposed a Free Trade Area.

As we know, there appeared a trite comparison of the region with the Central Asia (CA), which was obviously justified, but the process there was heading in the opposite direction. The integration structure became disintegrated. What is meant here is the Central Asian Union organisation which ceased to exist in 2005.

Normalisation of relations between Belgrade and Pristina is a crucial, if not a vital, condition (since it is not related to integration, we will get back to this matter later on).

Although Serbia does not rank first among the directions of the Russian foreign policy, the Serbians have shown sustainable attention to the Russia. The RF's Foreign Policy Concepts always support the United Nations (the UN) in various formulations. The country's leadership is permanently keeping its focus on the conflict revolving around Kosovo. Members of the Russian Parliament have always supported Serbia in discussions related to the Kosovo crisis in the Parliamentary Assembly of the Council of Europe (PACE) [9].

Kosovo declared its independence unilaterally in 2008. Only a third of the UN member states recognise this independence. Among the opponents of separatism there are, of course, Russia and Serbia. Cyprus, Greece, Romania, Slovakia and Spain (EU member states) do not recognise Kosovo as an independent state. As it was mentioned before, normalisation of relations is one of the accession requirements. For the accession negotiations to open, it is crucial that Russia removes its veto which does not allow Kosovo to join the UN. The negotiations under the EU Special Representative for the Serbia-Kosovo Dialogue were held with the facilitation of the EU in June 2020, but they did not yield any significant results. The parties agreed to continue the dialogue. Kosovo urged the USA to intensify its role on the process. In September 2020, representatives of Serbia and Kosovo pledged to participate in negotiations on normalisation of relations facilitated by the EU and stated that they assign the highest priority to the EU integration. President of Serbia, Prime Minister of Kosovo, and EU High Representative for Foreign Affairs and Security Policy issued a joint statement in which they expressed their commitment to intensify their efforts to adhere to the EU requirements. Serbia and Kosovo confirmed that the agreement on dialogue signed in Washington could facilitate a fully comprehensive legally binding agreement on normalisation of relations and arranged for cooperation in a number of economic fields to attract investment and create jobs. They referred to the emerged economic tie between Serbia and Kosovo as "a huge step forward".

When Moscow used its veto in the UN Security Council (UN SC), it ensured that Kosovo would not join the UN, as well as many other international organisations [11]. The Ministry of Foreign Affairs of Russia insists that the UN Security Council Resolution 1244 has been fulfilled. It is emphasised that the Resolution does not stipulate any specific measures of settlement; it demands that the question has been resolved in the open dialogue between Belgrade and Pristina respecting to Serbia's territorial integrity. Russia is going to facilitate the solving process at its best capacity. Yet 1999's Resolution does not feature any clues about Kosovo's independence; it is only about its substantial autonomy as a part of Serbia. Today it is impossible to imagine that Kosovo would, under any circumstances, agree to be ruled by Belgrade, even symbolically [11]. The experts had mentioned various possible scenarios and claim that "Russia will accept any decision that adheres to the interests of Serbia"1. In the meantime, the matters of dispute do not decrease in number. The relations between Belgrade and Pristina aggravated once again after the government of Kosovo imposed a 100 percent customs fee on all goods coming from Serbia and Bosnia [3, p. 123]. Pristina claims that there was no hidden political motive and emphasises that Kosovo's import from Serbia (440 million euro) is twenty times larger than its export. Yet the decision about the customs fees was made just a few days after Kosovo could not join Interpol. Having decided on this extreme increase of customs fees, the government of Kosovo breached the regional Free Trade Agreement and the Agreement on the Stabilisation and Association Agreement with the EU. It is what was reminded in work of (Sysoev,

\footnotetext{
1 Bondarev N., Entina E., Iskenderov P., Bondarenko O. Tri stsenariya dlya Kosovo [Three Scenarios for Kosovo] // Balkanist, Мау 13, 2019 [Электронный ресурc]. URL: https://balkanist.ru/tri-stsenariya-dlya-kosovo/ (дата обращения: 13.06.2020).
} 
2018 $)^{1}$. When Kosovo decided to form the so-called Kosovo army, it was met with highly negative public reaction as well.

According to the Resolution no. 1244 (1999), the UN SC remains the main platform for the international dialogue with respect to Kosovo. Given the recent aggravation, the UN SC has to take firm control over the matter and, in line with the established practice, hold open briefings on it. The situation in the region is extremely volatile and can break loose at any given moment. As a matter of fact, a semi-annual report presented by the leader of the Organisation for Security and Co-operation in Europe (OSCE) on the recent meeting of the OSCE Permanent Council contained a similar assessment. Kosovo remains the main source of volatility and conflict potential in the Balkans. Its leadership has taken course towards aggravation of the crisis, which poses a threat of continuous violence and war. During the reporting period, Pristina conducted a large number of provocations directed at Serbia and the Serbians of the autonomous region. The "government" of Kosovo, while violating all its obligations under the CEFTA, imposed a customs fee of 100 percent on all the goods from Serbia and Bosnia and Herzegovina. The measures are still in effect despite the requests coming from President of Serbia. Unsteady demands to revoke the fees coming from the USA and the EU are not backed by any real countermeasures, and Pristina simply ignores them. One of the underlying reasons is that "Brussels is not putting pressure where it should, but rather where it can: - on Belgrade" [3, p. 126]. In addition to that, on December 14, 2008 the so-called "Parliament" passed the decision to transform the Kosovo Security Force into a Kosovo "army". In doing so, it violated the provisions of the UN Security Council Resolution no. 1244 (1999). As the General Secretary of the UN pointed out again, this Resolution remains the only fundamental international legal basis of the Kosovo settlement. It contains a direct demand: groups and to permit presence of Multinational Brigades solely under the international control. One can refer to a discussion in the UN SC.

As an example, let us refer to the discussion in the UN SC that was held on February 7, 2019 with the following agenda: Report of the Secretary-General on the United Nations Interim Administration Mission in Kosovo ${ }^{2}$. As the agenda suggests, the relations between Kosovo and Serbia were in issue. It is obvious that matters discussed within the UN SC reach far beyond simple political conversations. Among the participants, there were representatives of the countries of the EU, the USA, Russia, and other countries. The main discussion revolved around two matters: views on reorganisation of the Kosovo Security Force, and the 100 percent tariff imposed on goods originating from Serbia and Bosnia and Herzegovina. Whereas the first matter was supported by the EU representatives unanimously, all the participants gave a negative assessment to the tariff. Serbia presented an important initiative right at that time; - it proposed a Free Trade Area within the Balkans ${ }^{3}$. The representative of Russia reminded that "According to the Resolution no. 1244 (1999), the UN SC remains the main platform for the international dialogue with respect to Kosovo"4. This is an obvious exercise of soft power.

\section{Soft Power and Further Development of the Serbia - EAEU Relations}

The EAEU's development entails a number of various tasks. They are not related to trade per se. For instance, the development of the following is frequently promoted:

- Distance learning facilitated by popular global online programs on educational platforms (Coursera, edX, etc.);

- This practice can enhance competition in education.

Education goes hand-in-hand with how the younger generations are raised and which values they share. Such mechanisms as, for example, panel discussions, which provide an informal environment to talk about

\footnotetext{
1 Sysoev G. Poshliny udarili po peregovoram. Evrointegratsiya Serbii i Kosovo zatyagivaetsiya [Tariffs Hit the Negotiations. European Integration of Serbia and Kosovo Is Dragged on] // Kommersant, November 27, 2018 [Электронный ресурc]. URL: https://www.kommersant.ru/doc/3812039 (дата обращения: 20.06.2020).

2 United Nations, United Nations Security Council Meeting Records S/PV.8459, 8459th Meeting, New York, February 7, 2019 [Электронный ресурс]. URL: https://undocs.org/en/S/PV.8459 (дата обращения: 27.07.2020).

3 Ibid.

4 Ibid.
} 
Eurasian matters and include engagement or work placement in the EAEU's bodies or particular projects, are not in issue.

Among the highlights of engagement, there are bilateral meetings at the highest level, participation in various international forums, energy and trade cooperation, a partner status within the framework of the Russian Agricultural Exhibition "Golden Autumn-2019". Serbian delegation's presence at these events boosts bilateral cooperation in the sphere of agriculture [15].

Over the course of many years, Serbia and Russia have held joint military exercises. To a large extent, they are symbolic. The same applies to the inter-parliamentary cooperation with the Parliamentary Assembly of Belarus-Russia Union and the Parliamentary Assembly of the Collective Security Treaty Organisation. It must be underlined that Serbia has taken real steps towards security alliance with NATO, and the exercises are held much more often. Even though the EU got stuck in the search for a less complicating process of its further enlargement, the Western Balkans are believed to join the Union inevitably; in light of this, the EU does not welcome any third countries' attempts to interfere with the process. It is pointless for Russia to step in this process and jeopardise its relations with the EU again.

In 2018, an Agreement on "International treaties of the EAEU with other countries, international integration associations, and other international organisations" was signed. For the EAEU, it became the main regulation document in this legal field. At the same time, the Supreme Eurasian Economic Council (the SEEC) ratified the Main directions of the international activities of the EAEU for 2019. According to both the expert and the research communities, the document displayed that the Union is open for interaction and mutually beneficial cooperation in all fields, regardless of the current challenges in the international relations. Similar to "The main directions of activity of the Government of the Russian Federation for the period until 2024", it highlights such fields as mutually beneficial connections between the EAEU and other countries and Free Trade Agreements with those countries.

The matters of the Western vector remain in focus, too: a new format of cooperation with Europe, first and foremost, with the EU countries and the European Free Trade Association (EFTA); development of inclusive cooperation in every field, including the updated mechanisms of interaction between the EAEU and the EU [8]. The EAEU presidency of the Republic of Armenia (2019) and the Republic of Belarus (2020) were marked with certain expectations in terms of advancing the cooperation between the EU and the EAEU, as both countries participate in the EU's "Eastern Partnership" initiative.

The "Main directions of the international activities of the EAEU for 2020" signed by the SEEC on October 1 stipulated that a Free Trade Agreement between the EAEU on one part and the Republic of Serbia on the other is one of the main directions of the EAEU's activity.

In other words, this Agreement was stipulated by a number of the EAEU's documents and it was successfully signed. The EAEU has ambitious plans to shape the Union to be a significant center of development in the modern world. Therefore, the Union, just as other integration associations, evidently utilises the best world practices, which include Free Trade Areas with their countries. Negotiations on FTA with Egypt, Israel, and India are planned to be concluded. The Agreement with Serbia is rather a sign of the Eurasian Economic Commission's success than of a long-term relationship prospect. Such practice proceeds as extension of cooperation is currently being negotiated with Southern Common Market (MERCOSUR), the Pacific Alliance, and Andean Community. At the same time, the EAEU promotes results-oriented cooperation with the EU. The agenda continuously involves such matters as cooperation with the EU's bodies specialising in technical regulation, sanitary and veterinary measures, pharmaceutical products and medical equipment trade, competition, and other technicalities.

The EAEU members' leadership assumes that such cooperation is common in the modern world. Similar practices are established within the countries of the Central Asia (including the EAEU's members) and the EU's countries, NATO, and the USA. The EU has special trade preferences with such countries as Armenia and Kyrgyzstan.

The EAEU's position is that the Union is one of the central nodes in the configuration of the Greater Eurasian Partnership's integration. This entails supporting both the Belt and Road initiative and the dialogue 
with the EU. Serbia and the EU have an evident interest in this. China is one of the most important trade parents for the European countries.

The EAEU's interaction with Serbia and, more broadly, with the WB exhibits an exercise of soft power in the international relations. Above all, this is important for the Russia. It is a chance to specify certain conceptual matters in the theory and practice of the international relations.

The regions of the Central Asia and the Western Balkans evidently have a lot in common. For instance, there are challenges of a transition period, armed conflicts, social tension, and ethnicity matters. The CA has not seen an aggravation of the confessional matter. Russia does not need to support the Orthodox Church.

The leadership of the CA countries, as well as, for instance, Serbia, has developed and followed a multivector foreign policy. It is a given, and it needs to be used correctly. Instead of a confrontation, it can bring up closer relations between the countries.

The EAEU and Russia are evidently more oriented towards the Central Asia rather than the Western Balkans, as opposed to the EU. In light of this, there is a hope that a certain "red threads" will emerge, and the states will not neglect them.

Russia needs a "mega-deal" between the EAEU and the EU not only in terms of free trade, but in terms of extensive economic integration with the EU. The examples of the EU-USA Transatlantic Trade and Investment Partnership (TTIP) and EU - Canada Comprehensive Economic and Trade Agreement (CETA) can be used in such integration.

Even though these negotiations appear to be a fantasy today, "even though the relations are deeply in crisis, we need to lay the foundation for the future negotiations and decisions now and sit at the table as soon as the circumstances allow for that" ${ }^{\prime 1}$.

\section{Conclusion}

To sum up, one of the main directions of modern integration processes development is the conclusion of Agreements on a Free Trade Area between the integration association and a separate economy / country. It was concluded that the signed Agreement is a format of cooperation that shows how exactly the EAEU and Serbia view it. The main goal of economic integration processes is economic growth, improving the wellbeing of the population and quality of life, free trade, development of its own production and sales markets for products, and building up industrial power based on economically profitable cooperation. It has been established that such cooperation is beneficial for both Serbia and the EAEU member states. Simultaneously, for the Russian Federation, Serbia serves as a gateway into Western Balkans for the projection of soft power in this region.

\section{References}

1. Andrei R. Energy Security in South-East Europe: Natural Resources as Causes of Conflict or Building Stability // Balkan Social Science Review. 2015. No. 5. P. 63-87.

2. Devetak S. Reconciliation - a Prerequiste for the Integration of the Western Balkans in the EU Stream of Values // Balkan Social Science Review. 2019. No. 14. P. 179-203.

3. Kandel P. Brussel's Strategies and Balkan Realities // Contemporary Europe - Sovremennaya Evropa. 2018. No. 7. P. 122-127. doi: 10.15211/soveurope72018130136. (In rus)

4. Kandel P. What Is New in the EU Strategy in the Western Balkans? //Contemporary Europe - Sovremennaya Evropa. 2018. No. 5. P. 17-24. doi:10.15211/soveurope520181724. (In rus)

5. Libman A. M., Heifetz B. Modeli ekonomicheskoy integratsii. Integratsiya i dezintegratsiya [Regional Integration Models. Integration and Disintegration] // Journal of Eurasian Economic Integration. 2011. No. 2 (11). P. 4-18. (In rus)

\footnotetext{
1 Vinokurov E. Evraziyskaya ekonomicheskaya integratsiya: uspekhi, neudachi, perspektivy, predely [Eurasian Economic Integration: Successes, Failures, Prospects, Limits] // Eurasian Development Bank - Eurasian Fund for Stabilization and Development, June 18, 2020 [Электронный ресурс]. URL: https://vinokurov.info/wp-content/uploads/2020/06/vinokurov_ancjea_2020.pdf (дата обращения: 05.08.2020).
} 
6. Maksakova M. A. Foreign Trade Problems of Serbia with the EU and EAEU // Russian Foreign Economic Journal. 2018. No. 1. P. 37-45. (In rus)

7. Maksakova M. A. Western Balkans on the Way to the European Union: Problems and Prospects // Russian Foreign Economic Journal. 2016. No. 11. P. 42-55. (In rus)

8. Meshkova T. A., Izotov V. S., Demidkina O. V., Kofner Y. The EAEU in a Changing Geopolitical Context: Priorities for International Cooperation // RUDN Journal of Political Science. 2019. No. 7, 21 (1). P. 7-33. doi: 10.22363/2313-1438-2019-21-1-7-33. (In rus)

9. Milikic R. Serbia and Russia in the Parliamentary Assembly of the Council of Europe (PACE) // Contemporary Europe - Sovremennaya Evropa. 2017. No. 5. P. 43-53. (In rus)

10. Prihodko A. A. (2018). Some Aspects of the Relationship of the Republic of Serbia and the Europaen Union: Problems and Prospects // Elektronnyy nauchnyy zhurnal «Arkhont» [Electronic Scientific Journal "Archont"]. 2018. No. 6 (9). P. 34-39. (In rus.)

11. Samorukov M. (2019, April 4). Novyy kosovskiy pretsedent. Kak Rossiya otreagiruyet na soglasheniye Belgrada i Prishtiny [New Kosovo Precedent. How Russia Will React to the Agreement between Belgrade and Pristina] // Carnegie Moscow Center [Электронный ресурc]. URL: https://carnegie.ru/2019/04/04/ ru-pub-78764 (дата обращения: 07.07.2020).

12. Simonovski I., Unsal E. Z. Balkan Region - Battleground for a Clash of the Centers of Power in a Creation of a New World Order? // Balkan Social Science Review. 2016. No. 8. P. 139-153.

13. Stojanovski S. From "Balkanization" Toward "West-Balkanization": The Republic of Macedonia's EuroAtlantic Prospects // Balkan Social Science Review. 2013. No. 1. P. 201-216.

14. Tosheva E., Dimeski B. (2019). The Competition Policy Western Balkan Countries: How Far They Have Come on the EU Accession Road // Balkan Social Science Review. 2019. No. 14. P. 31-55.

15. Yakimova V. Iz Rossii v EAES. Vsled za soglasheniyem s RF o svobonoy torgovle Serbiya vstupayet v zonu svobodnoy torgovli i so stranami EAES [From Russia to the EAEU. Following the Free Trade Agreement with the Russian Federation, Serbia Enters a Free Trade Zone with the EAEU Member-States] // Vestnik APK [Электронный ресурc]. URL: https://vestnikapk.ru/articles/aktualno/iz-rossii-v-eaes/ (дата обращения: 14.06.2020).

16. Yazkova A. A. (2012). Balkany na puti v ES: itogi i perspektivy [Balkans on the Road to the EU: Results and Prospects]. In O. Yu. Potemkina \& N. Yu. Kaveshnikov \& N. B. Kondrat'yeva (eds.) // Evropeyskiy soyuz v 21 veke: vremya ispytaniy [The European Union in the XXI Century: Time of Testing]. P. 337-353. Moscow, Ves' mir. (In rus)

\section{About the author:}

Andrey V. Toropygin, Professor of the Chair of International Relations of the Chair of Economics and Finance of North-West Institute of Management of the Russian Presidential Academy of National Economy and Public Administration (Saint Petersburg, Russian Federation), Doctor of Science (Political Sciences); toropyginav@mail.ru

\section{6 авторе:}

Торопыгин Андрей Владимирович, профессор кафедры международных отношений Северо-Западного института управления РАНХиГС (Санкт-Петербург, Российская Федерация), доктор политических наук; toropyginav@mail.ru 